\title{
CRIME, HISTÓRIA E NARRATIVA
}

Rafael Pereira da Silva*

FAUSTO, Boris. O crime do restaurante chinês: carnaval, futebol e justiça na São Paulo dos anos 30. São Paulo: Companhia das Letras, 2009. 246p.

Palavras-chave: inquérito; raça; confissão

Keywords: investigation; race; confession

Assassinatos, inquéritos e julgamentos transformam-se em tramas que assistimos diariamente nos diversos veículos de comunicação. Casos como o do casal Nardoni ou o seqüestro das adolescentes Eloá e Nayara são exemplos típicos da violência vendida como espetáculo. A literatura e o cinema, por sua vez, reforçam nosso imaginário com personagens que, de algozes podem às vezes ganhar simpatia dos leitores ou expectadores. Juntam-se a essas alegorias o futebol e o carnaval, manifestações coletivas transformadas em ícones da nacionalidade durante o período Vargas e temos de maneira análoga o enredo do novo livro do historiador Boris Fausto.

Professor aposentado do Departamento de Ciência Política da USP, membro da Academia Brasileira de Ciências, Fausto é autor do clássico Revolução de 30: historiografia e história, além de outros estudos como Negócios e ócios, Getúlio Vargas: o poder e o sorriso, bem como de ter dado continuidade, nos anos 1970, ao projeto historiográfico idealizado por Sérgio Buarque de Holanda da História geral da civilização brasileira.

Em O crime do restaurante chinês o autor narra a história de Arias de Oliveira, mulato, migrante, pobre que, assim como tantos outros (i)migrantes chegavam a São Paulo na busca de melhores oportunidades. No cenário da maior cidade do país um crime: quatro pessoas brutalmente assassinadas.

A partir desse microcosmo, o foco se expande para questões mais abrangentes, tendo como base as investigações, o inquérito policial e o julgamento do suspeito de

\footnotetext{
* Doutorando em História da Unicamp. Mestre em História Cultural pela UFSC.
} 
cometer tal atrocidade. As vítimas: um casal de chineses, donos de um restaurante na rua Wenceslau Braz, próximo à praça da Sé, um imigrante lituano e um brasileiro, todos funcionários do estabelecimento que, segundo o narrador, mal tiveram chances de reagir.

O processo-crime, as notícias policiais e as fotografias que ilustram a obra servem como matéria-prima da narrativa, que transcorre de forma fluída tal como nos bons textos literários. O carnaval de 1938 é o ponto crucial da trama. Arias de Oliveira, o migrante que veio de Franca para a cidade grande reflete o mais fiel estereótipo do criminoso consagrado pela cientificidade dos ensinamentos do italiano Césare Lombroso. Ex-empregado do restaurante, o migrante deixou o trabalho para cair na folia de momo daquele ano, não imaginando que sua vida se transformaria num enredo que duraria alguns anos.

Nesse contexto, há destaque ainda para a Copa do Mundo da França no mesmo ano e para os acontecimentos posteriores que resultariam na segunda guerra mundial em 1939 . Boris Fausto analisa nos dezesseis capítulos do livro os debates envolvendo a promotoria e a defesa. No centro das discussões, duas correntes de pensamento advindas do século XIX. A primeira, chamada de jurídico-racionalista encarava o indivíduo como sujeito de direitos e deveres, ou seja, era, portanto, moral e penalmente responsável por suas ações.

A outra chamada de psicológico-determinista via o indivíduo alienado, não na condição de sujeito, mas como objeto de seus impulsos, pulsões, fobias, paixões e desejos, de tal modo que as estruturas do comportamento estariam aquém da consciência e da vontade.

No inquérito e no processo aberto pela promotoria, tendo Arias de Oliveira como réu, se destacou os preceitos da Escola Positiva, expressão maior do determinismo. A Escola se caracterizava por um discurso médico-científico que patologizava o ato antissocial, encarando o criminoso como um doente; o crime, como um sintoma; a pena ideal para a prática de um delito, um tratamento e não um castigo.1

O trabalho, delimitado pelo próprio autor como de micro-história, traz ainda temas pertinentes a história social. Num contexto em que se discutia a nacionalidade, a questão da "raça" era lugar comum nas diversas interpretações, mesmo após a publicação de Casa Grande \& Senzala por Gilberto Freyre em 1933 . Muito mais do que explorar o debate de

\footnotetext{
${ }^{1}$ FAUSTO, Boris. O crime do restaurante chinês: carnaval, futebol e justiça na São Paulo dos anos 30 . São Paulo: Companhia das Letras, 2009. p.88-89.
} 
maneira maniqueísta, Boris Fausto coloca o tema como um campo de disputas, mencionando a existência de uma "pequena burguesia de cor" responsável por publicações como "A voz da Raça" e pela criação de entidades de classe, como por exemplo, a Frente Negra.

Nesse campo de forças a Frente Negra de São Paulo exercia um papel fundamental: socorria "companheiros de cor" em situação difícil. Embora acontecidas em plena década de 1930, histórias como essas remetem ao século XIX, o que significa dizer que a formação da classe trabalhadora no Brasil nas primeiras décadas republicanas não se consolidou com base na imagem congelada de "imigrante, anarquista, sindicalista". Muito pelo contrário, ela se constituiu numa continuidade de experiências advindas da sociedade escravista e nesse contexto, os fundos de mútua ajuda para a compra de liberdade naquele período eram mais comuns do que se imaginava, o que nos faz pensar na situação descrita por Fausto a respeito de sua personagem central, claro que, com devidas diferenças. 2

Seria essa a salvação de Arias? Os desdobramentos do julgamento, em especial a disputa acirrada entre acusação e defesa, tinham como temas de debate a idéia de confissão e os métodos utilizados no inquérito policial. A esta altura o réu já ganhava a simpatia da opinião pública e quiçá dos leitores dos jornais que cobriam o crime, entre notícia e outra da grande guerra. Nesse caso, a idéia de alguns veículos de imprensa de colar a imagem do réu a do Diamante Negro, ídolo brasileiro na copa de 1938, sensibilizava os leitores, ao mesmo tempo em que passava a idéia de inocência do acusado. Mas Arias não tinha um álibi e havia confessado o crime. Como terminaria o julgamento?

Se a narrativa se constitui como ponto forte deste livro, por outro lado, as discussões centrais tratadas não são novidade no debate historiográfico. Temas como as teorias raciais, a formação do proletariado, o darwinismo social, a migração/imigração ou a transformação de São Paulo em metrópole a partir dos anos 20 que já foram temas de livros como 0 espetáculo das raças (1993) de Lilia Schwartz ou Orfeu extático na metrópole (1992) de Nicolau Sevcenko.

Mas isso pouco importa nessa obra. As motivações e a justificativa apresentadas por Boris Fausto ao escolher esse crime e não outros são reveladores de um trabalho feito por

\footnotetext{
${ }^{2}$ CHALHOUB, Sidnei. A enxada e o guarda-chuva: a luta pela libertação dos escravos e a formação da classe trabalhadora no Brasil (manuscrito). Palestra apresentada no XXI Simpósio da Anpuh. Niterói, jul. 2001.
} 
quem muito já contribuiu com a historiografia nacional. Por fim, o autor busca algumas elucidações que ligam suas memórias ao momento da escrita da história. Nas lembranças, imagens da morte da mãe e das fantasias que a imprensa criou sobre Arias. As respostas ficam em aberto. Mas, as tentativas de encontrá-las se concretizaram neste livro.

Recebido em 25/11/2009.

Aprovado para publicação em 14/12/2009. 